\section{Prosedur Pemberian Sertifikat Label Halal Terhadap Produk Makanan Di Restoran Hotel Syariah Untuk Mewujudkan Hak Kenyamanan Konsumen Muslim (Studi Di Kementerian Agama Provinsi Sumatera Utara) \\ Mukidi $^{1}$ \\ mayormukidi@gmail.com}

\section{Abstract}

Businessmen have the duty of ensuring halal food products and giving the halal label on the basis of having obtained a halal certificate from the ministry of religion which was socialized to the consumer society in a way that it is conveyed through writings that are easy to read and not easily removed by a visitor at a particular place in the restaurant. It is according to Article 39 of Law Number 33 Year 2014 concerning the guarantee of halal products. The halal certificate is valid for four years since it was issued by the Halal Product Guarantee Agency (HPGA), and it must be extended. Halal certificates are mandatory, so the food products which do not have halal label certificate cannot longer circulate in Indonesia.

The procedure for obtaining halal certification at the hotel restaurant which was issued by the Ministry of Religious Affairs (MORA). First, businessmen must fulfill the requirements which were checked by HPGA such as, the data of businessmen, the name and type of business product, a list of products and materials used, the manner or the product processing as well as halal guarantee system. After fulfilling the requirements of HPGA in checking the dokumen, then determine the $L P H$ that has been selected by the applicant, then the $L P H$ conducts the examination and / or testing of the next step of the MUI product through the determination of the halal food product halal through a halal fatwa session. After the process is carried out through the prescribed stages, the HPGA issues a halal certificate.

Keywords : Halal Label Certification, Halal Products, Halal Product Protection Guarantees

\footnotetext{
${ }^{1}$ Dosen Fakultas Hukum UISU
}

\section{Abstrak}

Pelaku usaha berkewajiban menjamin produk makanan halal dan mencantumkan label halal atas dasar telah mendapatkan sertifikat halal dari kementerian agama yang disosialisasikan kepada masyarakat konsumen dengan cara yang disampaikan melalui tulisan-tulisan yang mudah dibaca dan tidak mudah dihapus oleh pengunjung di tempat tertentu di restoran sesuai bunyi Pasal 39 Undang-Undang Nomor 33 Tahun 2014 tentang jaminan produk halal. Sertifikat halal tersebut berlaku selama empat tahun sejak diterbitkan oleh Badan Penyelenggara Jaminan Produk Halal (BPJPH), dan wajib diperpanjang. Sertifikat halal bersifat wajib (mandatory) sehingga produk pangan yang tidak berlabel halal tidak bisa lagi beredar di Indonesia.

Prosedur untuk mendapatkan sertifikasi halal pada restoran hotel yang dikeluarkan oleh Kementrian Agama (Kemenag), pelaku usaha harus memenuhi persyaratan yang diperiksa oleh BPJPH antara lain data pelaku usaha, nama dan jenis produk usaha, daftar produk dan bahan digunakan, cara atau proses pengolahan produk serta sistem jaminan halal. Setelah memenuhi syarat BPJPH melakukan pemeriksaan dokumen selanjut menetapkan LPH yang telah dipilih oleh pemohon kemudian LPH melakukan Pemeriksaan dan /atau pengujian kehalalan produk langkah berikutnya MUI melalui penetapan kehalalan produk makanan halal melalui sidang fatwa halal. Setelah proses terlaksana melaui tahapan yang ditentukan, maka BPJH menerbitkan sertifikat halal.

Kata Kunci : Sertifikasi Label Hal, Produk Halal, Jaminan Produk Halal Perlindungan Konsumen.

\section{Pendahuluan}

\section{A. Latar Belakang}

Jaminan penyelenggaraan produk halal bertujuan memberikan kenyamanan, keamanan, keselamatan dan kepastian ketersediaan produk halal bagi masyarakat dalam mengkonsumsi dan menggunakan produk halal, serta meningkatkan nilai tambah bagi pelaku usaha untuk memproduksi dan menjual produk makanan halal di restoran. 
Media Komunikasi dan Informasi Hukum dan Masyarakat

Jaminan Produk makanan halal menjadi penting mengingat kemajuan ilmu pengetahuan dan teknologi di bidang pangan yang berkembang pesat. Hal ini berpengaruh secara nyata pada pergeseran pengolahan dan pemanfaataan bahan baku untuk makanan dari yang semula bersifat sederhana dan alamiah menjadi pengolahan dan pemanfaatan bahan baku hasil rekayasa ilmu pengetahuan. UndangUndang produk makanan halal adalah barang yang terkait dengan makanan. Sedangkan yang dimaksud dengan produk halal adalah produk makanan halal yang telah dinyatakan halal sesuai dengan syariat Islam.

Untuk membuat produk makanan halal di restoran melalui prosedur yang sudah diatur dalam hukum Islam melalui syariat-syariatnya dan dilaksanakan dalam tindakan atau operasional yang harus dijalankan atau dieksekusi dengan cara yang baku (sama) agar selalu memperoleh hasil yang halal.

Prosedur pencantuman jaminan produk halal sudah diatur dalam Undang Undang Nomor 33 Tahun 2014 tentang Jaminan produk halal dan Undang Undang Nomor 8 Tahun 1999 tentang perlindungan konsumen dan peraturanperaturan pemerintah dan lembaga lainnya yang terkait untuk menjamin kepastian kehalalan produk makanan bagi umat muslim. UndangUndang dan peraturan pemerintah tersebut berlaku sampai tanggal 16 Oktober 2019 sebelum disahkan dalam Badan Penyelenggara Jaminan Produk Halal (BPJPH) resmi beroperasi pada tanggal 17 Oktober 2019. Sesuai pasal 67 dari Undang-Undang Nomor 33 Tahun 2014 tentang Jaminan Produk Halal (JPH) yang menyebutkan aturan harus berlaku lima tahun setelah Undang-Undang ini disahkan. Jika dilihat dari alur mekanisme dan prosedur untuk mendapatkan sertifikat halal terhadap produk makanan di RESTORAN pada hotel syariah mengalami perubahan dan birokrasi yang lebih efektif. Menurut BPJPH yang telah resmi dioperasikan pada tanggal 17 Oktober 2019 bahwa semua produk makanan wajib mencantumkan sertifikat halal dari Badan Penyelenggara Jaminan Produk Halal (BPJPH) di bawah Kementerian Agama (Kemenag) dan sertifikat halal tidak lagi diterbitkan Majelis Ulama Indonesia (MUI) seperti peraturan yang telah berlaku sebelumnya.

Pelaku usaha berkewajiban menjamin produk makanan halal dan mencantumkan label halal atas dasar telah mendapatkan sertifikat halal dari kementerian agama yang disosialisasikan kepada masyarakat konsumen dengan cara yang disampaikan melalui tulisan tulisan yang mudah dibaca dan tidak mudah dihapus oleh pengunjung di tempat tertentu di restoran sesuai bunyi Pasal 39 UndangUndang Nomor 33 Tahun 2014 tentang jaminan produk halal. $^{2}$

$$
\text { Jaminan produk makanan halal }
$$
disosialisasikan atas dasar restoran telah mendapatkan sertifikat halal. Sertifikat halal tersebut berlaku selama empat tahun sejak diterbitkan oleh Badan Penyelenggara Jaminan Produk Halal (BPJPH) dan wajib diperpanjang oleh Pelaku Usaha dengan mengajukan pembaruan Sertifikat Halal paling lambat tiga bulan sebelum masa berlaku Sertifikat Halal habis.

Sertifikat halal bersifat wajib (mandatory) sehingga produk pangan yang tidak berlabel halal tidak bisa lagi beredar di

LP POM MUI Edisi Nomor 65 Tahun XI 2007. Jurnal Halal, Zona Halal untuk Melindungi Masyarakat, LP POM MUI Edisi Nomor 70 Tahun XI 2007. Jurnal Halal, Susu Formula Bermasalah, Halal Jangan Dilupakan, LP POM MUI Edisi Nomor 71 Tahun XI 2007. Jurnal Halal, Menyorot Kosmetika, 97\% Tidak Jelas Kehalalannya, LP POM MUI Edisi Nomor 73 Tahun XI 2007, LP POM MUI Edisi Nomor 74 Tahun XI 200 
Media Komunikasi dan Informasi Hukum dan Masyarakat

Indonesia, baik yang diproduksi di dalam negeri maupun yang berasal dari luar negeri. Pelaku usaha yang telah memperoleh sertifikat halal wajib mencantumkan label halal pada kemasan produk, bagian tertentu dari produk dan/atau tempat tertentu pada produk. Peran pemerintah dalam melakukan pengawasan terhadap beredarnya produk pangan yang tidak bersertifikat halal diatur dalam Undang-Undang Pangan dan Undang-Undang Jaminan Produk Halal (JPH).

\section{B. Permasalahan}

Berdasarkan latar belakang di atas maka dapat ditarik sebuah permasalahan sebagai berikut:

1. Bagaimana prosedur sertifikasi pencantuman label halal untuk menjamin kepastian kehalalan produk makanan?

2. Bagaimana urgensi pemberian sertifikat halal terhadap restoran beserta pada Hotel Syariah dihubungkan usaha perhotelan sebagai usaha yang memerlukan perizinan?

\section{Metode Penelitian}

Penelitian ini menggunakan jenis penelitian Penelitian Hukum yuridis empiris dan yuridis normative. Penelitian yuridis empiris dilakukan untuk mengidentifikasi konsep dan asas-asas serta prinsip-prinsip prosedur dan mekanisme dalam mendapatkan sertifikat produk makanan halal di restoran untuk menjamin kehalalan produk dan kenyamanan bagi konsumen muslim.

Penelitian yuridis normatif yaitu pendekatan yang dilakukan berdasarkan bahan hukum utama dengan cara menelaah teoroteori, konsep-konsep, asas-asas hukum serta peraturan perundang-undangan yang berhubungan dengan penelitian dan emperis yaitu penelitian yang berfokus meliti suatu fenomena atau keadaan dari objek penelitian secara setail dengan menghimpum kenyataan yang terjadi serta mengembangkan konsep yang adaPenelitian yuridis normatif adalah pendekatan yang dilakukan berdasarkan bahan hukum utama dengan cara menelah teori-teori, konsep-konsep, asas-asas serta peraturan perundang-undangan yang berhubungan dengan penelitian ini.

Peneliti melakukan penilaian terhadap pelaksanaan sertifikasi halal yang digunakan dan juga membuat kesimpulan. Sifat penelitian yang digunakan dalam penelitian adalah penelitian Kualitatif, yakni prosedur yang menghasilkan data deskriptif berupa kata-kata tertulis atau lisan dari orang-orang dan perilaku yang dapat diamati. Hal ini digunakan karena ada beberapa pertimbangan yakni pertama, penelitian kualitatif yang tentunya menggunakan metode kualitatif lebih mudah apabila berhadapan dengan kenyataan ganda; kedua, metode ini menyajikan secara langsung hakikat hubungan antara peneliti dengan responden dan ketiga, metode ini lebih peka dan lebih dapat menyesuaikan diri dengan banyak penajaman pengaruh bersama terhadap polapola nilai yang dihadapi. Metode kualitatif ini, secara garis besar dibedakan dalam dua macam, yakni kualitatif interaktif dan non interaktif. Metode kualitatif interaktif, merupakan studi yang mendalam menggunakan teknik pengumpulan data langsung dari orang dalam lingkungan alamiahnya. ${ }^{3}$ Penelitian kualitatif mengkaji perspektif partisipan dengan strategistrategi yang bersifat interaktif dan fleksibel. Penelitian kualitatif ditujukan untuk memahami fenomena-genomena sosial dari sudut pandang

3 Rijal Arifin. 2001, Mengenal Jenis dan Tekhnik Penelitian, Erlangga, Jakarta, hal, .288 
Media Komunikasi dan Informasi Hukum dan Masyarakat

partisipan. Dengan demikian pengetian penelitian kualitatif adalah penelitian yang digunakan untuk meneliti pada kondisi objek alamiah dimana peneliti merupakan instrumen kunci.

Data tertier adalah suatu kumpulan dan kompilasi sumber primer dan sumber sekunder. Contoh sumber tertier adalah biografi, katalog perpustakaan, direktori, dan daftar bacaan. Ensiklopedia dan buku teks adalah contoh bahan yang mencakup baik sumber sekunder maupun tertier, menyajikan pada satu sisi komentar dan analisis, dan pada sisi lain mencoba menyediakan rangkuman bahan yang tersedia untuk suatu topik.

Teknik pengumpulan data diperoleh Data primer merupakan data yang dikumpulkan secara langsung oleh peneliti atau pihak pertama.

Analisis data yang digunakan dalam penelitian ini adalah analisis secara kualitatif yaitu uraian yang dilkukan peneliti terhadap data yang terkumpul tidak menggunakan statistik atau matematika ataupun sejenisnya tetapi berupa uraian-uraian kalimat yang tersusun secara sistematis sesuai dengan permaslahan yang dibahas dalam penelitian ini.

Dalam menarik kesimpulan penulis menggunakan metode dedukatif yaitu merupakan cara berfikir yang menarik kesimpulan dari suatu pernyataan atau dalil yang bersifat umum menjadi suatu pernyataan yang bersifat khusus.

\section{Pembahasan}

A. Prosedur Sertifikasi Pencantuman Label Halal Untuk Menjamin Kepastian Kehalalan Produk Makanan

Seluruh produk makanan wajib mencantumkan sertifikat halal dari Badan
Penyelenggara Jaminan Produk Halal (BPJPH) di bawah Kementerian Agama (Kemenag). Hal ini sesuai dengan amanat Undang-undang tentang Jaminan Produk Halal (JPH) yang diundangkan oleh Presiden ke-6 RI Susilo Bambang Yudhoyono pada 17 Oktober 2014 yang lalu. Pasal 67 Ayat 1 Undang-Undang tersebut menyatakan kewajiban bersertifikat halal bagi produk yang beredar dan diperdagangkan di wilayah Indonesia mulai berlaku lima tahun terhitung sejak UndangUndang diundangkan.

Dalam beleid juga tercantum, bahan yang digunakan dalam Proses Produk Halal $(\mathrm{PPH})$ terdiri atas, bahan baku, bahan olahan, bahan tambahan, dan bahan penolong. Bahan tersebut berasal dari hewan, tumbuhan, mikroba, dan bahan yang dihasilkan melalui proses kimiawi, biologi, atau proses rekayasa genetik. Seluruhnya wajib halal sesuai fatwa Majelis Ulama Indonesia (MUI). Pelaku usaha juga wajib memisahkan lokasi, tempat dan penyembelihan, alat pengolahan, penyimpanan, pengemasan, pendistribusian, penjualan, dan penyajian antara produk halal dan tidak halal.

Pelaku Usaha yang telah memperoleh Sertifikat Halal wajib mencantumkan Label Halal terhadap Produk yang telah mendapat Sertifikat Halal, dan menjaga kehalalan Produk yang telah memperoleh Sertifikat Halal. Pengusaha juga wajib memperbarui Sertifikat Halal jika masa berlaku sertifikat halal berakhir, dan melaporkan perubahan komposisi Bahan kepada BPJPH. Sebelumnya, sertifikasi produk halal dilakukan LPPOM MUI. Namun, per 17 Oktober 2019, kewenangan itu sepenuhnya berada di tangan pemerintah melalui BPJPH Kementerian Agama. 
Media Komunikasi dan Informasi Hukum dan Masyarakat

BPJPH dapat membentuk perwakilan di daerah. Ketentuan mengenai tugas, fungsi, dan susunan organisasi BPJPH diatur dalam Peraturan Presiden. Lembaga berwenang merumuskan dan menetapkan kebijakan JPH, termasuk menetapkan norma, standar, prosedur, dan kriteria JPH. Selain itu, menerbitkan dan mencabut sertifikat halal dan label halal pada produk, serta meregistrasi sertifikat halal pada produk luar negeri. BPJPH juga berwenang melakukan sosialisasi, edukasi, dan publikasi produk halal.

Namun kenyataanya, aturan-aturan di atas masih belum sepenuhnya ditaati oleh kalangan produsen. Sebagian besar produk yang beredar di restoran hotel di kota Medan hanya mencantumkan label halal namun belum memiliki sertifikat halal. Banyak produsen makanan yang secara pribadi menempelkan tulisan halal tanpa seizin MUI menurut UndangUndang yang berlaku pada tahun 2014. Atas adanya fakta tersebut, MUI meminta masyarakat sebagai konsumen harus teliti. ${ }^{4}$

Hingga saat ini, belum ada satu pun hotel di Medan yang mengantongi sertifikat halal dari Lembaga Pengkajian Pangan, Obat-obatan, dan Kosmetika (LPPOM) MUI. Kondisi ini sangat miris di tengah pertumbuhan bisnis hotel yang cukup signifikan di kota ketiga terbesar di Indonesia. Menurut Basyaruddin, tidak hanya hotel biasa pada umumnya yang belum memiliki sertifikat halal, bahkan sejumlah hotel yang selama ini tercitrakan sebagai hotel bernuansa islami juga belum mengurus sertifikasi halal.

Sertifikasi halal adalah bagaimana kemampuan sebuah produksi itu menjamin najis itu untuk tidak terlibat di dalamnya atau terkontaminasi di dalamnya. Menerbitkan

${ }^{4}$ MUI: 54 Persen Makanan Yang Beredar di Pasaran Tidak Halal," www. Globalmuslim.web.id. diakses 21 Agustus 2013. sertifikat halal supaya orang tidak ragu karena kemajuan teknologi saat ini banyak hal-hal yang merugikanumat muslim karena bahan makanan tidak standart menurut hukum Islam. Pertumbuhan ekonomi di beberapa kota di Indonesia memang terus mengalami dampak positif.

Akibat dari semakin berkembanganya dan pesatnya perekonomian ini, maka tidak heran jika semakin banyak hotel-hotel bermunculan diberbagai kota di Indonesia termasuk di Medan yang merupakan Ibu Kota dari Sumatera Utara. Di Medan dengan semakin meningkatkanya ekonomi kota tersebut membuat hotel semakin banyak dan menjamur, ini tentu positif bagi perekonomian setempat dan juga nasional. Meskipun ada banyak hotel baru di kota Medan, ternyata dari banyak hotel yang ada di Medan belum memiliki sertifikasi halal yang diterbitkan oleh Kemenag.

Berdasarkan data dari Majelis Ulama Indonesia (MUI) tahun 2018 kota Medan, dari 2.500 lebih restoran yang ada di kota Medan, baik restoran kecil, sedang dan besar, ternyata baru $5 \%$ saja yang bersertifikat halal. ${ }^{5}$ Artinya, banyak produk makanan berlabel halal palsu berkeliaran di tengah masyarakat. Banyak rumah makan, restoran, kafe, atau produk makanan/minuman mengklaim produknya halal tetapi tidak memiliki sertifikat halal. Banyak Usaha Kecil Menengah (UKM), restoran, dan pengusaha katering mencantumkan label halal padahal tidak mengikuti prosedur memperoleh sertifikat halal dari MUI sebelum beralih proses kepengurusannya ke lembaga Kementrian agama.

Produk makanan tersebut hanya bertuliskan label halal tanpa ada sertifikat MUI

${ }^{5}$ Kabar Medan.com diakses tanggal 29 Juli 2018 pukul . 17.30 wib. 
Media Komunikasi dan Informasi Hukum dan Masyarakat

padahal sertifikat halal asli hanya dikeluarkan MUI waktu itu. Produk halal bodong juga tersebar luas di kantin-kantin kampus. Bentuknya pun beragam, mulai roti, kue basah, kue kering, minuman dan lain sebagainya. Tapi, banyak orang yang tidak sadar dan tidak memperhatikan keberadaan logo halal tersebut.

Di tengah geliat Medan sebagai Kota Metropolitan dengan munculnya hotel-hotel megah, kenyataan miris tentang kepedulian para pengusaha untuk mengurus sertifikasi halal terungkap sangat minim. Padahal hotel adalah tempat yang tidak hanya memberikan kenyamanan untuk menginap, tapi juga menyajikan makanan-makanan enak dan halal. Samapai saat ini belum ada satupun di Medan yang benar-benar sudah memiliki sertifikasi halal. Pada saat peresmian Musala Al Mualaf di Komplek J City, pihaknya sudah memberikan imbauan kepada hotel-hotel untuk mengurus sertifikasi halal tersebut.

Pengurusan sertifikat halal bukan lagi wewenang lembaga pengkajian pangan, obat obatan dan kosmetika Majelis Ulama Indonesia (LPPOM MUI) Berdasarkan aturan tersebut, pengurusan sertifikat halal menjadi wewenang badan penyelenggara jaminan produk halal (BPJPH) di bawah naungan Kementerian Agama.

Kementerian Agama mencatat selama ini produk makanan yang memiliki sertifikat produk halal masih sedikit paling sekitar $2 \%$, karena selama ini sifatnya masih sukarela. ${ }^{6}$ Akibat dari kebijakan pemerintah sebelum tahun 2019 sehingga para pengusaha restoran hotel dan para pelaku usaha kecil dan menengah

\footnotetext{
'Lukman Hakim Saifuddin, Kementrian agama tentang penjelasan kepengurusan sertifikat label halal,https://nasional.okezone.com/read/2019/10/08/337/211 4286/menag-lukman-ingatkan-sertifikasi-halal-produkmakanan-dan-minuman-mulai-17-oktober diakses pada tanggal 24 November 2019 . pukul 15.56 Wib.
}

tidak serius dalam mendapatkan sertifikat makanan halal.

Panganan khas dari Medan misalnya Bolu Meranti yang terkenal kelezatannya dan Risol Spesial Gogo ternyata sudah tak memiliki label halal dari Majelis Ulama Indonesia (MUI). Informasi ini sudah beredar luas di media sosial dalam bentuk surat dengan nomor 182/C/LPPOM/MUI-SU/IX/17, dan memancing berbagai komentar. Dalam surat yang ditandatangani oleh Ketua Komisi Fatwa MUI Sumut, Ramli Abdul Wahid dan Direktur LP POM MUI Sumut Basyaruddin dalam surat tersebut dijelaskan bahwa Bolu Meranti yang beralamat di Jalan Kruing No. $2 \mathrm{~K}$ Medan dengan nama perusahaan Commanditaire Vennootschap (CV) Cipta Rasa Nusantara tidak dapat melengkapi persyaratan untuk memenuhi standar Sertifikasi Halal/Sistem Jaminan Halal. Dalam surat itu termuat, sertifikasi halal Bolu Meranti sudah berakhir sejak April 2015, namun beredarnya surat ini di media sosial justru membuat bingung masyarakat, senada dengan Bolu Meranti, Risol Spesial Gogo yang beralamat di Jalan Mojopahit No. 53 Medan sudah tidak memiliki sertifikasi halal dari MUI sejak tahun 2012.

Dalam surat itu dikatakan, perusahaan makanan tersebut tidak melakukan proses perpanjangan sertifikat halal sampai batas waktu yang telah ditentukan. Ketua Majelis Ulama Indonesia (MUI) Kota Medan, Muhammad Hatta menyebutkan, banyak produk makanan yang belum berlabel halal di Kota Medan, Sumatera Utara.

Adapun alur cara membuat sertifikat halal di BPJPH Kemenag:

a. Pemohon mendaftarkan diri dengan melampirkan sejumlah persyaratan dokumen (terdiri dari data pelaku usaha, nama dan jenis produk, daftar produk dan 
Media Komunikasi dan Informasi Hukum dan Masyarakat

bahan yang digunakan, dan proses pengolahan produk).

b. BPJPH akan meneliti seluruh persyaratanpersyaratan yang diajukan Anda.

c. Pemohon menentukan LPH untuk memeriksa produk yang dijual atau dimakan.

d. LPH akan melakukan pemeriksaan atau pengujian produk yang dijual atau dimakan, kemudian hasilnya diserahkan ke MUI untuk mendapatkan fatwa halal sebuah produk. LPH adalah lembaga yang melakukan kegiatan pemeriksaan dan/atau pengujian terhadap kehalalan produk.

e. Dari hasil pemeriksaan LPH, MUI melaksanakan penetapan kehalalan produk melalui sidang fatwa halal.

f. BPJPH selanjutnya akan menerbitkan sertifikat dan label halal berdasarkan hasil fatwa MUI.

Berikut Proses sertifikasi halal dalam bentuk diagram alir Undang-Undang (UU) No. 33 thn 2014 yang telah disetujui oleh Rapat Paripurna DPR-RI pada 25 September 2014, dan juga telah disahkan oleh Presiden Republik Indonesia, Susilo Bambang Yudhoyono pada tanggal 17 Oktober 2014.

Kerancuan yang terjadi pada proses dan mekanisme kepengurusan dalam mendapatkan sertifikat halal produk makanan di restoran hotel, sebelum diberlakukan UndangUndang Nomor 33 Tahun 2014 Tentang Jaminan Produk Halal per 17 oktober 2019 di kota medan akibat pemberlakuan secara sukarela dan alur kepengurusan yang berbeda.

Tidak terkecuali baik hotel yang bersifat syariah ataupun konvensional bahkan sebagian hotel bekerjasama dengan restoran dan pengusaha produk makanan lain untuk tambahan menu makanan diluar hotel yang tidak memiliki sertifikat halal dari Kementrian Agama yang dijual direstoran hotel sampai dengan tahun 2019 akibat tidak tegasnya pemerintah dalam menerapkan Udang-Undang yang mengatur tentang sertifikat halal baik dalam bentuk produk makanan. Berikut daftar hotel dikota medan menggunakan sistem syariah.
a. Hotel Grand Impresion.
b. Grand Kanaya
c. Grand Impresion
d. Garuda Plaza
e. Raz Hotel
f. Grand Jamee
g. Grand Darussalam

Sesuai penelitian penulis untuk mengetahui kelengkapan persyaratan sistem syariah yang diterapkan di hotel tersebut diatas tidak mendapatkan kejelasan dari masingmasing pengusaha hotel dengan berbagai macam alasan yang disampaikan dan sebagian besar dari hotel diatas tidak mengurus sertifikat halal justru.

\section{B. Urgensi Pemberian Sertifikat Halal Terhadap Restoran Hotel Syariah Dihubungkan Usaha Perhotelan Sebagai Usaha Yang Memerlukan Perizinan}

Peran pemerintah sangat penting dalam jaminan kehalalan produk yang beredar di masyarakat, baik itu produk dalam negeri maupun impor. Hal ini tentu saja telah menjadi poin penting bagi Kementrian Agama (Kemenag). Maka pada 11 Oktober 2017, pemerintah meresmikan BPJPH (Badan Penyelenggara Jaminan Produk Halal) yang merupakan perwujudan dari amanat UU No. 33 Tahun 2014 tentang Jaminan Produk Halal (JPH). Kini penyelenggara sertifikasi halal beralih dari yang semula dilakukan oleh MUI, kini oleh BPJPH di bawah naungan Kemenag.

Membangun literasi halal bertujuan untuk memberikan persamaan persepsi semua pihak 
Media Komunikasi dan Informasi Hukum dan Masyarakat

akan pentingnya keberadaan jaminan produk halal. Hal ini teramat penting baik bagi konsumen karena dapat menimbulkan rasa aman dan nyaman, juga bagi produsen dan penjual sebab dapat meningkatkan penjualan yang berpotensi untuk diekspor. Sebagai langkah awal, BPJH harus segera melakukan sosialisasi yang lebih masif dan inklusif untuk mendorong kesadaran dan kepedulian para pelaku usaha dan masyarakat tentang pentingnya jaminan produk halal.

Peran penting BPJPH yang lain adalah : Merumuskan dan menetapkan kebijakan JPH, Menuntaskan sistem informasi halal dan mekanisme pendaftaran permohonan sertifikasi halal dengan berlandaskan prinsip kerja professional, transparan, pro aktif dan biaya terjangkau, Melakukan pembinaan auditor halal, Penentuan kehalalan produk, Menerbitkan dan mencabut sertifikat halal, Melakukan sosialisasi, edukasi dan publikasi produk halal. Untuk menyongsong berlakunya sistem mandatori dalam penyelenggaraan jaminan produk halal, BPJPH harus segera menyiapkan Sumber daya Manusia (SDM), sarana prasarana, sistem dan pertanggungjawaban produk halal. Dengan kesiapan ini, BPJPH menjamin proses sertifikasi produk halal hanya membutuhkan waktu tidak lebih dari 60 hari kerja. ${ }^{7}$

Kehadiran BPJPH dapat menjamin kenyamanan konsumen sebab produk yang sudah diberi label halal sudah pasti melalui proses produksi yang thayib (baik), higienis dan terbuat dari bahan yang aman dikonsumsi. Halal merupakan gaya hidup dan identitas seorang muslim, sebab Halal Itu Baik seperti yang termaktub dalam Al-Qur'an Surat Al-Baqarah ayat 168 ,

Wahai manusia ! Makanlah dari (makanan) yang halal dan baik yang terdapat di bumi dan janganlah kamu

${ }^{7}$ http://nasional.kontan.co.id/news/kemenag-bpjphharus-ambil-langkah-seribu diakses pada tanggal 15 Desember 2019 pukul 16. 00 wib mengikuti langkah-langkah setan. Sesungguhnya setan itu musuh yang nyata bagimu.

Untuk mewujudkan penjelasan Surat Albaqarah ayat 168 diatas pra pelaku usaha restoran hotel dan produser produk makann selain harus memiliki perizinan usaha, sertifikasi halal produk makanan menjadi hal yang wajib dimiliki. Pencantuman label halal dari BPJPH ini penting tidak hanya untuk konsumen, tapi juga untuk para produsen. Label halal ini gunanya memberikan rasa aman bagi para konsumen juga sebagai jaminan untuk produk yang dikonsumsi tersebut aman dari unsur yang tidak halal dan diproduksi dengan cara halal dan beretika.

Untuk produsen, label halal ini berfungsi dalam membangun kepercayaan dan loyalitas konsumen terhadap produk-produk tersebut. Produk yang bersetifikat halal juga jadi memiliki daya saing yang lebih tinggi dibanding produk yang tidak mencantumkan label halal di produknya. Produk tradisional yang dilakukan secara serius dan luar biasa. Selain itu, Lukman pun mengatakan mengacu pada UndangUndang Produk Halal Nomor 23 Tahun 2014 bahwa rencananya tahun 2019 pemberlakukan mandatori halal bahwa semua produk yang masuk dan berdagang di Indonesia harus memiliki sertifikat halal.

Agar konsumen muslim nyaman mengkonsumsi produk makanan yang diinginkan ditinjau dari perspektif hak asasi manusia, produk halal adalah kewajiban yang harus dipenuhi oleh pemerintah. Produk halal adalah bagian tak terpisahkan dari hak asasi manusia. Pemerintah Indonesia harus menghormati hak-hak masya rakat dengan memenuhi tuntutan penyediaan produk produk halal. Hal ini dimaksudkan agar 
Media Komunikasi dan Informasi Hukum dan Masyarakat

konsumen merasa aman, tentram dan yakin bahwa produk yang dikonsumsi adalah halal. Pemerintah harus mengadakan sertifikasi halal bagi semua produk yang dipasarkan baik produk impor maupun produk lokal kepada masyarakat.

Pemerintah Indonesia juga tidak membiarkan warganya untuk mengkonsumsi produk-produk yang berbahaya pada kesehatan dirinya. Terbukti dengan adanya Peraturan Pemerintah No. 69 Tahun 1999 tentang pangan halal. Pangan halal (pasal 1 ayat 5) adalah pangan yang tidak mengandung unsur atau bahan yang haram atau dilarang untuk dikonsumsi umat Islam, baik yang menyangkut bahan baku pangan, bahan tambahan pangan, bahan bantu dan bahan penolong lainnya termasuk bahan pangan yang diolah melalui proses rekayasa genetika dan iradiasi pangan, dan yang pengelolaannya dilaku kan sesuai dengan ketentuan hukum agama Islam agar tidak menghalangi ibadah bagi masyarakat muslim.

Urgensi sertifikasi halal bagi konsumen, Pangan halal menjadikan suatu syarat bahwa kehalalan suatu produk akan menentramkan konsumen. Produk halal tidak saja memenuhi kebutuhan aspek keimanan dan ketakwaan, melainkan juga terjaga dari segi kualitas dan higienisnya. $^{8}$ Secara tidak langsung produsen membantu konsumen dalam memperoleh makanan halal. Itulah sebabnya, produk halal amat didambakan dan dicari oleh konsumen Muslim. ${ }^{9}$ Sementara konsumen non-Muslim juga dijamin memperoleh produk yang diproses secara sehat, bersih dan aman dikonsumsi.

\footnotetext{
${ }^{8}$ Arnia, Warganegara, E. 2013. Identifikasi Kontaminasi Bakteri Coliform Pada Daging Sapi Segar Yang Dijual Di Pasar Sekitar Kota Bandar Lampung. MAJORITY (Medical Journal of Lampung University)

${ }^{9}$ Wati Rahmi Ria dan Muhammad Zulfikar, IImu Hukum Islam, Gunung Pesagi, Bandar Lampung, 2015, hal. 15.
}

Dengan adanya sertifikasi halal pada rumah potong ayam merupakan sebuah proses untuk menghasilkan daging ayam yang halal, memang sudah harus menjadi hak dari pada konsumen muslim.

Urgensi sertifikasi halal bagi produsen Perusahaan ayam potong dalam proses pelaksanaan penyembelihan dan daging hasil penyembelihannya dipercaya konsumen kehalalannya. Hal dapat meningkatkan daya beli konsumen terhadap rumah potong ayam yang bersertifikat. Produsen juga merasa lebih aman dalam melaksanakan penyembelihan. Kepuasan konsumen terhadap hasil produksi yang di pasarkan oleh perusahaan telah diatur dalam Undang - Undang Perlindungan Konsumen. Dalam hal ini ketika ada suatu kesalahan yang disengaja oleh produsen,maka konsumen dapat dilindumgi hak-haknya. ${ }^{10}$

Urgensi sertifikasi halal bagi nilai agama Islam Daging yang disembelih dengan cara yang tradisional atau moderen tetapi dengan tidak dibacakan basmallah rasa dan bentuknya akan sama saja dengan yang dibacakan basmallah, tidak dapat dibedakan sama sekali. Namun ada nilai keimanan ketika mengkonsumsi daging yang penyembelihannya sesuai dengan syari'at Islam. Oleh karena itu, diperlukan proses sertifikasi dan pengawasan yang ketat terhadap rumah-rumah potong hewan, khususnya rumah potong ayam yang banyak tersebar dengan skala dari mulai kecil sampai besar, sedangkan rumah potong hewan besar relatif lebih terkontrol karena biasanya dilakukan di pejagalan dengan pengawasan yang cukup ketat.

Urgensi sertifikasi halal bagi lingkungan Pencemaran lingkungan hidup adalah masuknya atau memasukkannya mahkluk hidup, zat, energi, dan/atau komponen lain ke dalam lingkungan hidup oleh kegiatan manusia sehingga kualitasnya

${ }^{10}$ Ahmadi Miru \& Sutarman Yodo. Hukum Perlindungan Konsumen. Rajawali Pers, Jakarta, 2008. 
Media Komunikasi dan Informasi Hukum dan Masyarakat

turun sampai tingkat tertentu yang menyebabkan lingkungan hidup tidak dapat berrfungsi sesuai peruntukkannya. Karena itu, dengan adanya sertifikasi halal produsen tidak hanya menjaga ketentraman hati konsumen terhadap daging ayam hasil penyembelihanya tetapi juga menjaga lingkungan sekitar dari limbah yang dihasilakan rumah potong ayam dari kegiatan pencemaran lingkungan. ${ }^{11}$

Urgensi sertifikasi halal bagi pemerintah, Majelis Ulama Indonesi (MUI) meminta pemerintah untuk menyerahkan sertifikat halal kepada Badan Penyelenggara Jaminan Produk Halal (BPJPH) dibawah Kemenag, pemberian wewenang kepada Badan Penyelenggara Jaminan Produk Halal (BPJPH) perlu dilakukan untuk menjaga indenpendensi. Sehingga sertifikasi tidak menjadi objek politik perdagangan pemerintah. Selain itu pada dasarnya persoalan halal atau tidak halal berada di ranah syari'ah. Dengan begitu masyarakat merasa dilindungi hak mengkonsumsi makanan halal sesuai syari'at oleh pemerintah. ${ }^{12}$

Hotel dan pelaku usaha restoran di hotel harus dilengkapi dengan Perizinan, sertifikasi halal menjadi sesuatu yang wajib dimiliki oleh sebuah usaha Produk makanan mengingat bahwa sebagian besar masyarakat Indonesia adalah muslim yang sangat sensitif terhadap makanan haram. Pencantuman label halal sangat penting bagi kedua pihak, yaitu produsen dan konsumen. Dengan adanya pencantuman label halal, konsumen lebih merasa aman dalam mengkonsumsi dan menggunakan produk atau makanan tersebut.

Legalitas formal tentang perizinan bagi perusahaan dan pelaku usaha harus dilengkapi oleh perizinan yang telah diatur pada UU No.3 Tahun 1982 Tentang Wajib Daftar Perusahaan termasuk penerbitan sertifikat halal produk makanan yang telah diatur pada Undang-

${ }^{11}$ Arya Wardhana, Wisnu. 2004. Dampak Pencemaran Lingkungan. Yogyakarta: Penerbit Andi Yogyakarta., hal 17

${ }^{12}$ QS. Al-Ma idah: 3
Undang Nomor 33 Tahun 2014 tentang Jaminan Produk Halal (JPH), Undang-Undang No. 8 Tahun 1999 tentang Perlindungan Konsumen Per-KBPOM Nomor 12 Tahun 2016 Tentang Pendaftaran Pangan Olahan dan peraturan peraturan pemerintah yang lain termasuk Badan Penyelenggara Jaminan Produk Halal (BPJPH).

Sekalipun diketahui bahwa Undang Undang yang berlaku belum dapat diterapkan secara baik karena keterkaitanya dengan budaya daerah setempat. Hal ini menjadikan hambatan terhadap pemerintah untuk mendapatkan kontribusi penghasilan sebagai kontribusi dalam bentuk pajak perizinan.

Masih terdapat hal-hal yang menjadi hambatan untuk mendapatkan perizinan bagi pelaku usaha restoran hotel dan produsen produk makanan. Dari sini memang perlunya adanya reformasi pada bidang perizinan khususnya yang menyangkut aspek ekonomi agar pelaku usaha bisa lebih baik dan ekonominya tertata rapi dengan tuntutan dari nasioanal dan Internasional yaitu ekonomi pasar bebas aktif, contoh kasus yang terjadi di Indonesia termasuk Jakarta banyak sekali tersedia berbagai macam hotel berbintang. Ada satu yang menarik perhatian, yaitu kehadiran hotel syariah. Produk syariah itu bagus untuk semua bukan hanya muslim saja, tetapi juga baik untuk non muslim. ${ }^{13}$ Misalkan dari makanan, muslim kebutuhan utama makanan halal dan semuanya halal, untuk tahu halal harus ada sertifikasi, ini semuanya sudah harus dapat sertifikat dari Kemenag melalui sidang fatwa halal MUI.

Undang-undang tentang sertifikat label halal telah diberlakukan di Indonesia sebagai prosuder untuk mendapatkan sertifikat label halal yang dilengkapi

${ }^{13}$ Direktorat Jenderal Bimas Islam dan Penyelenggaraan Haji Departemen Agama, 2003, Petunjuk Tekhnis Pedoman sistem Produksi Halal, Jakarta, hal. 6 
Media Komunikasi dan Informasi Hukum dan Masyarakat

dengan organisasi untuk mendukung terlaksananya permohan pernerbitan sertifikat halal baik pelaku usaha restoran hotel ataupun produser produk makanan untuk menciptakan keamanan dan kenyamanan konsumen. Undang-undang tersebut untuk mengatur terealisasinya sertifikat halal yang terkait dengan jaminan halal produk makanan yang diperkuat oleh peraturan-peraturan pemerintah, Kementrian agama dan Badan Penyelenggara Jaminan Produk Halal (BPJPH) dengan tujuan untuk menciptakan keamanan dan kenyamanan produk makanan, terutama untuk konsumen muslim. ${ }^{14}$

Jika melihat mekanisme dan prosedur seperti yang dijelaskan diatas sampai saat ini prosedur sertifikasi pencantuman label halal untuk menjamin kepastian kehalalan produk makanan belum bisa terealisasi secara baik, karena sulitnya organ-organ yang mempunyai kewenangan untuk mentransfer aturan-aturan yang berlaku.

Kenyataan dilapangan menunjukkan bahwa banyak prodak makanan baik dipasar maupun direstoran hotel masih belum terlihat secara nyata terliat terdapat label halal diberbagai produk makanan. Walaupun prosedur sertifikasi kehalalan sudah dilengkapi dengan undang-undang, peraturan pemerintah, peraturan menteri dan lembaga-lembaga pemerintahan dan dikoordinir oleh Badan Penyelenggara Jaminan Produk Halal (BPJPH) sebagai penetapan kehalalan produk namun belum terlaksanan secara maksimal. ${ }^{15}$

Dari kenyataan yang ada prosedur sertifikasi jaminan label halal masih belum mampu terealisasi untuk menjamin kehalalan produk makanan karena dari berbagai produk

\footnotetext{
${ }^{14}$ Anwar, Ali, 2007. Tinjauan Islam terhadap Makanan dan Minuman. Tersedia di http://www.unpas.ac.id/file:///D:/aims/pangan\%20halal/panga n\%20dalam\%20pandangan\%20islam.htm. Diakses 6 Desember 2007

15 Sabiq, Sayyid. 1997 , Fikih Sunah , PT Alma'arrif , Bandung, hal. 47
}

makanan belum tertempel label halal. Dari uraian diatas benar adanya bahwa jika terlaksana prodak makanan dari perusahaan dan restoran telah tertempel tulisan label halal yang dikeluarkan oleh Kemenag akan dapat menjamin kehalalan produk makanan. Namun kesungguhan dari pemerintah tetap diharapkan untuk menjalankan prosedur yang sudah ditentukan agar dapat terpelihara mekanisme dan prosedur berlakunya sertifikat halal yang dikeluarkan Kemenag, intinya yaitu pemerintah harus konsekuen dan konsisten untuk menerapkan prosedur dan memberikan kemudahan-kemudahan dalam kepengurusan sertifikat label halal prodak makananbaik pada pelaku usaha restoran hotel ataupun para pelaku usaha produsen produk makanan.

Sertifikat halal berlaku selama 4(empat) tahun sehingga masyarakat untuk mengkonsumsi makanan atau minuman yang dijamin kehalalannya cukup tinggi. ${ }^{16}$ Untuk itu, pemerintah Indonesia berkewajiban melindungi masyarakat akan konsumsi makanan halal. Makna makanan halal adalah sejenis makanan yang tidak mengandung unsur atau bahan yang haram yang dilarang untuk dikonsumsi oleh umat Islam, baik yang menyangkut bahan baku pangan, bahan tambahan pangan, bahan bantu dan bahan penolong lainnya termasuk bahan pangan yang diolah melalui proses rekayasa genetika dan iradiasi pangan, dan yang pengelolaannya dilakukan sesuai dengan ketentuan hukum agama Islam.

Hak untuk memperoleh kehidupan yang layak termasuk hak untuk mengkonsumsi pangan dan menggunakan produk lainnya yang dapat menjamin kualitas hidup dan kehidupan manusia. Pada pasal 30 ayat 1 Undang -

16 Syaikh Al-Fauzan, 1988,Al-Ath'imah wa Ahkamis Shoyd wadz Dzaba ih, Maktabah Al-Ma'arif ArRiyadh, hal. 122 
Media Komunikasi dan Informasi Hukum dan Masyarakat

Undang Nomor 7 Tahun 1996 tentang Pangan disebutkan setiap orang yang memproduksi atau memasukkan ke dalam wilayah Indonesia makanan yang dikemas untuk diperdagangkan wajib mencantumkan label di dalam, dan atau di kemasan pangan. ${ }^{17}$

Hal ini menuntut peningkatan peran serta masyarakat, pemerintah, penegak hukum dan lembaga swadaya masyarakat dalam hal ini lembaga perlindungan konsumen swadaya masyarakat (LPKSM) sebagaimana di atur dalam Undang-undang No 8 Tahun 199 tentang Perlindungan Konsumen.

Permasalahan yang timbul perlu diperbaiki untuk pelaksanaan jaminan produk halal di lapangan. Ketentuan mengenai perlindungan konsumen ini (sebenarnya) telah tercantum dalam pembukaan Undang - Undang Dasar 1945 alinea IV yang menyebutkan bahwa Negara Indonesia melindungi segenap bangsa Indonesia dan seluruh tumpah darah Indonesia. Oleh karena itu, hadirnya Undang-undang Jaminan Produk Halal mempresentasikan tanggung jawab negara, khususnya terhadap umat Islam untuk melindungi dan memberikan rasa tenang dan aman dalam mengkonsumsi/menggunakan produk yang sesuai syari'at yakni halal dan thoyib. ${ }^{18}$

Kegiatan sertifikasi halal di Indonesia baru dilakukan sejak didirikan LPPOM MUI pada 1989 namun pada tanggal 17 Oktober 2019 menjadi bulan berlakunya Undang-Undang JPH secara penuh, sedangkan ketentuan teknis tentang pelaksanaan labelisasi yang didasarkan atas hasil sertifikasi halal, baru dikeluarkan tahun 1996 yaitu Keputusan Menteri Kesehatan

\footnotetext{
${ }^{17}$ Syarief, R. dan S. Santausa. 2010. Teknologi Pengemasan Pangan. Laboratorium Rekayasa Proses Pangan, PAU Pangan dan Gizi, IPB. hal. 12

${ }^{18}$ Jazuli Juwaini, "UU JPH Untuk Melindungi Umat", Jur- nal Halal, No. 95 Th. XV Tahun 2012: LPPOM MUI, Jakarta, HIm.30
}

RI No. 82/ Menkes/SK/l/1996 tentang Pencantuman Tulisan "Halal" pada Label Makanan. Berkaitan dengan hal tersebut Kepmenkes RI Nomor 82/ Menkes/SK///1996, menyatakan tegas dalam Pasal 17.

Berdasarkan keputusan tersebut, izin pencantuman label halal dikeluarkan oleh Direktorat Jenderal Pengawasan Obat dan Makanan Depkes RI (sekarang menjadi Badan Pengawas Obat dan Makanan/Badan POM) baik kedudukan, tugas, fungsi dan kewenangan berdasarkan sertifikat halal yang dikeluarkan oleh Kemenag.

Peraturan yang lebih tinggi yang menaungi atas ketentuan sertifikasi dan halal antara lain Undang-Undang Nomor 18 Tahun 2012 tentang Pangan terutama Pasal 86 ayat(4) jo Pasal 95, 96, 97 dan Undang-Undang Nomor 8 Tahun 1999 tentang Perlindungan Konsumen (UUPK). Hal itu diperkokoh dengan UUPK pada Pasal 8 (h). Oleh karena itu, perusahaan yang akan melakukan pelabelan halal secara legal harus melakukan sertifikasi halal. Hal ini untuk menghindari adanya pernyataan halal yang tidak valid. Suatu perusahaan yang membuat pernyataan halal secara tidak valid dapat dikenakan sanksi sesuai dengan Pasal 62 ayat (1) UUPK, karena termasuk sebagai pelanggaran terhadap Pasal 8 (h) dari UU tersebut.

Proses sertifikasi halal yang dilakukan oleh Kemenag melalui MUI dan Komisi Fatwa ini sudah melalui tahapan kontruksi pikir yang merupakan keharusan untuk mengarahkan hukum kepada cita-cita yang diinginkan masyarakat (dalam hal ini konsumen dan pelaku usaha). Meminjam istilah Rudolf Stamler inilah yang disebut dengan cita hukum. ${ }^{19}$

${ }^{19}$ Rudolf Stamler dalam Roeslan Saleh, "Pembinaan Cita Hukum dan Penerapan Asas-asas Hukum Nasional', 
Media Komunikasi dan Informasi Hukum dan Masyarakat

Cita hukum tersebut ialah Pokok Pikiran yang terkandung dalam Pembukaan UndangUndang Dasar 1945, cita hukum tersebut tidak lain ialah Pancasila. Selain itu Pancasila telah ditetapkan para pendiri negara Proklamasi ini sebaga Norma yang tertinggi dalam kehidupan kenegaraan rakyat Indonesia, sebagai Norma Dasar Negara (Staatsgrundnorm). ${ }^{20}$ Cita hukum berfungsi sebagai "bintang pemandu" bagi tercapainya cita-cita masyarakat.

Meski merupakan titik akhir yang tidak mungkin dicapai, namun cita hukum memberi manfaat karena yang berlaku, dan kepada cita hukum dapat mengarahkan hukum positif sebagai usaha mengatur tata kehidupan dengan sanksi pemaksa, menuju suatu yang adil. Oleh karena itu, menurut Stammler, keadilan ialah usaha atau tindakan mengarahkan hukum positif kepada cita hukum. Dengan demikian, maka hukum yang adil ialah hukum yang diarahkan oleh cita hukum untuk mencapai tujuan-tujuan masyarakat. ${ }^{21}$

Ada beberapa contoh kasus yang telah sangat menyakiti konsumen Muslim di Indonesia yang pada akhirnya menimbulkan kerugian besar bagi produsen dan dunia usaha, yaitu: kasus bakso mengandung daging babi di Bandung (1984), kasus makanan yang memakai bahan dari babi di Malang (1988). ${ }^{22}$

Menyikapi hal ini, Majelis Ulama Indonesia (MUI) melalui Komisi Fatwa telah berikhtiar untuk memberikan jaminan produk

Ma- jalah Hukum Nasional, No.1 tahun 1995, Jakarta, Depkeh, hal. 49

${ }^{20} \mathrm{~A}$. Hamid S. Attamimi, "Aktualisasi Hukum Islam", Jur nal Mimbar Hukum, Vol. V No. 13 Tahun 1994, Al-Hikmah dan Ditbinbapera, Jakarta, hal.1-2

${ }^{21} \mathrm{KN}$. Sofyan Hasan, "Cita Hukum (rechtsidee) dan Cita Negara (staatsidee) sebagai Landasan Hukum Indonesia", Jurnal Hukum, Vol. VIII No. 2 Tahun 2010, Palem- bang: Program Pascasarajana Univ. Sriwijaya, hal. 3

${ }^{22}$ Ma'ruf Amin, "Fatwa Halal Melindungi Umat dari Ke- rugian yang Lebih Besar", Jurnal Halal, No.103 Th. XVI Tahun 2013, LPPOM MUI, Jakarta, hal.20 makanan halal bagi konsumen muslim melalui sidang fatwa halal. Sertifikat halal merupakan fatwa tertulis Majelis Ulama Indonesia yang menetapkan kehalalan suatu produk mealui sidang fatwa halal. Sertifikat halal selain sebagai perlindungan konsumen dari berbagai macam makanan yang dianggap tidak layak sesuai syari'at Islam khusunya Indonesia yang mayoritas beragama Islam, juga mendorong kompetisi dan menjadi keunggulan. Sertifikat halal saat ini menjadi salah satu poin untuk daya saing di perdagangan internasional.

$$
\text { Kementrian Agama melakukan }
$$

pengkajian dan pemeriksaan dari tinjauan sains terhadap produk yang akan disertifikasi. Jika berdasarkan pendekatan sains telah didapatkan kejelasan, maka hasil pengkajian dan pemeriksaan tersebut dibawa ke Komisi Fatwa untuk dibahas dari tinjauan syari'ah Islam. Pertemuan antara sains dan syari'ah inilah yang dijadikan dasar penetapan oleh Komisi Fatwa, yang selanjutnya dituangkan dalam bentuk sertifikat halal oleh Kemenag.

Akibat dari sistem pengaturan yang tidak konsisten, tumpang tindih dan tidak sistemik. Juga yang paling mendasar, sertifikasi halal itu bukan merupakan suatu kewajiban (mandatory) bagi pelaku usaha, akan tetapi bersifat sukarela (voluntary). Menteri Koperasi dan UKM, bahwa dalam konteks perdagangan internasional, penerapan label halal dan sertifikasi halal merupakan hal yang strategis sebagai salah satu defence mechanism, yang dimungkinkan oleh Word Trade Organization (WTO) untuk meningkatkan daya saing produkproduk Indonesia dalam kompetisi dengan produk-produk yang berasal dari negara-negara non-muslim.

Sejalan dengan problematika yang ada, sikap MUI meminta agar pencantuman sertifikat 
Media Komunikasi dan Informasi Hukum dan Masyarakat

halal menjadi suatu kewajiban bagi produsen makanan, bukan hanya upaya sukarela saja. Di samping memang dalam rangka memuaskan pihak kosumen, namun di lain sisi juga dapat menaikkan mutu produk yang ada di pasaran lokal dan internasonal. Dengan memiliki sertifikat dan tanda halal yang diterbitkan oleh Kemang dapat menjadi standar ukuran kualitas mutu produk makanan bagi produsen. Bahkan kini, Sertifikat Halal (SH) Kemenag terasa sangat dibutuhkan kalangan pengusaha dan produsen pangan. Bukan hanya oleh keluarga Muslim atau umat Islam, namun juga diperlukan oleh hampir semua umat dan produsen yang berasal dari beragam agama. ${ }^{23}$ Dewan Perwakilan Rakyat (DPR) tetap menginginkan agar kewenangan sertifikasi halal berada di tangan Kemenag sebagaimana yang sudah berjalan pada tanggal 17 Oktober 2019.

Wakil Presiden Republik Indonesia Ma'Ruf Amin menegaskan bahwa penentuan ke-halalan haruslah dikeluarkan melalui fatwa ulama melalui sidang komisi fatwa namun 17 Oktober 2019 menjadi bulan berlakunya Undang-Undang JPH secara penuh yang diterbitkan oleh Kemenag. Ulama yang diwadahi MUI dengan berbagai ormas di dalamnya melaksanakan penetapan kahalalan produk melalui sidang fatwa MUI. Menurut wakil presiden Republik Indonesia bahwa selama ini MUI menerbitkan sertifikasi halal untuk itu pada tahun 2019 tanggal 17 Oktober 2019 Kemenag yang memiliki otoritas dalam penerbitan sertifikat halal, adapun proses labeling produk tetap ada pada Badan Pengawas Obat dan Makanan (BPOM). ${ }^{24}$ Permintaan ini tentu tidak berlebihan, mengingat selama 25 tahun mengemban amanah di bidang sertifikasi halal, LPPOM MUI telah menunjukkan peran dan kinerjanya

${ }^{23} \mathrm{H}$. Roichan Muchlis, "Halal Mendongkrak Ekonomi Bali", Jurnal Halal, No.97 Th. XV Tahun 2012, LPPOM MUI, Jakarta, hal. 29

${ }^{24}$ Din Syamsuddin, Rabu, 5 Maret 2014, Sertifikasi Halal Negara Non Muslim Lebih Baik, Harian Republika, Republika, Jakarta, hal. 9 dengan baik, bahkan telah pula diakui oleh lembaga-lembaga sertifikasi halal dari berbagai negara. ${ }^{25}$

Sertifikasi juga harus menjangkau bahan baku, bahan tambahan maupun bahan penolong dalam bentuk "bukan kemasan" yang tidak diecerkan untuk bahan produk makanan dan produk lainnya yang beredar di masyarakat. Sertifikasi produk halal diberlakukan tidak hanya terhadap produk dalam negeri tetapi juga produk luar negeri. Mengenai produk yang bersertifikat halal dari lembaga sertifikat luar negeri, perlu diperhatikan bahwa tidak semua standar luar negeri atau internasional dapat diterapkan di Indonesia karena di Indonesia batasan halal adalah yang paling ketat dan tidak dapat disimpangkan. Misalnya di luar negeri babi yang telah berubah menjadi $X$ dapat menjadi tidak diharamkan lagi, sedangkan di Indonesia babi yang telah mengalami perubahan apapun tetaplah diharamkan. ${ }^{26}$

Terdapat sejumlah lembaga yang terlibat dalam persoalan halal haram suatu produk, yaitu Kementrian Agama, BPJPH, LPH, Badan POM, dan MUI (Komisi Fatwa MUI, LPPOM-MUI), Departemen Pertanian tergabung dalam Komite Halal Indonesia (KHI). Sertifikat halal berlaku dua tahun dan dapat diperbaharui untuk jangka waktu yang sama. Setiap pelaku usaha yang telah mendapatkan sertifikat halal terhadap produknya mencantumkan keterangan atau tulisan halal dan nomor sertifikat pada label setiap kemasan produk yang telah diterbitkan sertifikat halal oleh Kemenag. Selama masa berlaku sertifikat

${ }^{25}$ Ma'ruf Amin, "25 Tahun LPPOM MUI, Luncurkan PRO HALAL MUP', Jurnal Halal, No. ${ }^{106}$ Tahun 2014, Jakarta : LPPOM MUI, hal. 42

${ }^{26}$ Ma'ruf Amin, "Mengapa Keharaman Babi Bersifat Mutlak", Jurnal Halal, No.99 Th. XVI Tahun 2013, Jakarta: LPPOM MUI, hal. 46-47 
Media Komunikasi dan Informasi Hukum dan Masyarakat

halal tersebut, perusahaan harus dapat memberikan jaminan bahwa segala perubahan baik dari segi penggunaan bahan, pemasok, maupun tekonologi proses hanya dapat dilakukan dengan sepengetahuan LPPOM MUI yang menerbitkan sertifikat halal namun sesuai Pasal 5 ayat (3) Undang-Undang Nomor 33 Tahun 2014 Tentang Jaminan Produk Halal mengatakan bahwa untuk melaksanakan penyelenggaraan JPH maka dibentuk BPJPH yang berkedudukan di bawah dan bertanggung jawab kepada Menteri, dalam hal ini adalah Menteri Agama.

Sertifikat halal dan labelisasi halal merupakan dua kegiatan yang berbeda tetapi mempunyai keterkaitan satu sama lain. Hasil dari kegiatan sidang fatwa halal MUI adalah diterbitkannya sertifikat halal oleh Kemanag, apabila produk yang dimaksudkan telah memenuhi ketentuan pemeriksaan oleh BPJH sebagai produk halal. Sertifikasi halal dilakukan oleh lembaga kementrian yang mempunyai otoritas untuk melaksanakannya. Tujuan akhir dari sertifikasi halal adalah adanya pengakuan secara legal formal bahwa produk yang dikeluarkan telah memenuhi ketentuan halal. Sedangkan labelisasi halal adalah pencantuman tulisan atau pernyataan halal pada kemasan produk untuk menunjukkan bahwa produk yang dimaksud berstatus sebagai produk halal.

Begitu pula, setiap pelaku usaha yang akan mencantumkan label halal harus memiliki sertifikat halal terlebih dahulu. Tanpa sertifikat halal Kemenag, izin pencantuman label halal tidak akan diberikan pemerintah. Sampai saat ini memang belum ada aturan yang menetapkan bentuk logo halal yang khas, sehingga pada umumnya produsen mencetak tulisan halal dalam huruf latin dan arab dengan bentuk dan warna yang beragam. Akan tetapi beberapa produsen sudah mulai membuat logo halal dengan bentuk logo MUI dengan mencantumkan nomor sertifikat halal yang dimilikinya. Hal ini dirasakan lebih aman bagi konsumen karena masih banyak produk yang beredar di pasaran yang mencantumkan label halal tanpa memiliki sertifikat halal Kemenag. ${ }^{27}$

Peraturan yang bersifat teknis mengatur masalah pelabelan halal antara lain keputusan bersama Menteri Kesehatan dan Menteri Agama RI Nomor 427/Men.Kes/SKB/VIII/1985 (No. 68 Tahun 1985) tentang Pencantuman Tulisan Halal Pada Label Makanan. Jelas bahwa tulisan halal yang dibubuhkan pada label atau penandaan makanan produknya, dianggap oleh hukum bahwa produsen tersebut secara sah telah memenuhi prosedur sertifikasi produk halal dari Kemenag.

Namun bila ternyata terbukti sebaliknya, maka produsen dapat dituntut secara hukum karena melakukan pembohongan publik. Di samping pelaku usaha harus bertanggung jawab atas label halal yang dicantumkan pada produknya, pengusaha juga berkewajiban melapor kepada pihak pemerintah yang dalam hal ini Departemen Kesehatan RI. Prosedur ini sebagaimana yang diamanatkan oleh Keputusan Bersama Menteri Agama dan Menteri Kesehatan. Hal itu dimaksudkan untuk memudahkan melakukan pengawasan selanjutnya.

Adanya regulasi tentang sertifikasi halal sebuah produk baik makanan merupakan bagian dari perlindungan terhadap konsumen khususnya yang beragama Islam. Penentuan status halal haramnya sebuah produk baik makanan bukanlah

${ }^{27}$ Paulus J. Rusli, "Nilai Unggul Produk Halal", Jurnal Halal, Nomor 59 Th X, LPPOM MUI, Jakarta, 2005, hal.15. 
Media Komunikasi dan Informasi Hukum dan Masyarakat

perkara mudah. Pada satu sisi para ulama mungkin belum seluruhnya menyadari betapa banyaknya produk pangan saat ini. ${ }^{28}$

Asal usul bahan bisa melalui jalur yang berliku, bahkan dalam beberapa kasus sulit untuk ditentukan asal bahannya. Dalam sisi lain, pemahaman para ilmuwan terhadap syariat Islam, ushul fikih dan metodologi penentuan halal haramnya suatu bahan pangan relatif minim. Dengan demikian, seharusnya para ulama mencoba memahami betapa kompleksnya produk pangan. Sedangkan ilmuwan Muslim seharusnya menggali kembali pengetahuan syariatnya untuk membantu ulama memahami kompleksitas masalah yang ada.

Sebagai negara dengan penduduk Muslim terbesar di dunia, sudah selaiknya Indonesia menjadi pilot project untuk menerapkan regulasi produk pangan dengan sertifikasi dan label halal. Senada dengan itu pula Majelis Ulama Indonesia (MUI) berharap kepada Kemenag untuk menegaskan kepada pelku usaha restoran hotel atas kewajiban dari pengusaha untuk mensertifikatkan ulang produk halal tersebut agar diterbitkan oleh Kemenang melalui sidang fatwa halal MUI.

Perlindungan atas konsumen merupakan hal yang sangat penting dalam hukum Islam. Islam melihat sebuah perlindungan konsumen bukan sebagai hubungan keperdataan semata melainkan menyangkut kepentingan publik secara luas bahkan menyangkut hubungan antara manusia dengan Allah SWT. ${ }^{29}$ Dalam konsep hukum Islam perlindungan atas tubuh terkait dengan hubungan vertikal (manusia

${ }^{28}$ Muchtaridi, 2004, Ekstrak plasenta antar khasiat dan kehalalan. Majalah NOOR. Edisi 05/Mei/2004.

${ }^{29}$ Daftar produk halal dapat dilihat di Jurnal Halal terbitan LPPOM MUI atau di http://www.www.halalmui.org, daftar ini memuat produk yang telah mendapatkan sertifikat halal dari MUI. dengan Allah SWT) dan horizontal (sesama manusia). Dalam Islam, melindungi manusia dan juga masyarakat sudah merupakan kewajiban sebuah negara sehingga melindungi konsumen atas barang-barang yang sesuai dengan kaidah Islam harus diperhatikan secara fokus dan serius.

Telaah terhadap perlindungan konsumen Muslim atas produk barang dan jasa menjadi sangat penting setidaknya disebabkan oleh beberapa hal, antara lain : Pertama, bahwa konsumen Indonesia mayoritas merupakan konsumen beragama Islam yang sudah selaiknya mendapatkan perlindungan atas segala jenis produk barang dan jasa yang sesuai dengan kaidah-kaidah hukum Islam. Berdasarkan hal tersebut maka masyarakat Islam (konsumen Muslim) harus mendapatkan perlindungan atas kualitas mutu barang dan jasa serta tingkat kehalalan suatu barang dan jasa yang ditawarkan oleh pelaku usaha. Kedua, bahwa Pemerintah Indonesia sudah melakukan upaya aktif untuk melindungi konsumenkonsumen yang mayoritas beragama Islam.

Perlindungan konsumen merupakan hak warga negara yang pada sisi lain merupakan kewajiban negara untuk melindungi warga negaranya khususnya atas produk yang halal dan baik. Pada dasarnya sertifikasi halal tidak cuma menguntungkan konsumen tetapi juga produsen. Dengan produk halal maka kepercayaan dan loyalitas konsumen akan meningkat. Selain itu, jika produk itu halal maka pasarnya bisa menjangkau semua kalangan, baik Muslim maupun non Muslim.

Sertifikasi Halal Wajib Berlaku 2019, mulai tahun 2019 seluruh produk yang beredar di Indonesia diwajibkan memiliki sertifikasi halal sesuai dengan Undang-undang (UU) Nomor 33 Tahun 2014 tentang Jaminan Produk Halal 
Media Komunikasi dan Informasi Hukum dan Masyarakat

(JPH). ${ }^{30}$ Meski Undang-Undang ini masih dalam tahap sosialisasi, namun pelaku usaha dan masyarakat harus mengetahui peraturan tersebut yang tidak hanya mengatur tentang makanan halal.

Kewajiban memiliki sertifikat halal bagi pelaku usaha restoran hotel bukan hanya untuk kepentingan umat Islam atau bentuk fanatik meski $85 \%$ penduduk Indonesia beragama Islam tapi ini untuk kepentingan umat manusia, apalagi riset telah membuktikan apa yang telah diharamkan oleh Islam dari Al-Qur'an.

Hal itu, menjadi dasar bagi umat Islam untuk tidak mengonsumsi dan memakai produk yang tidak halal. Karena dalam UU JPH nanti, akan ada rencana peralihan penerbitan sertifikat halal oleh Badan Penyelenggara Jaminan Produk Halal (BPJPH).

Jadi selama BPJH belum aktif, sertifikat yang sudah dikeluarkan sebelumnya tetap berlaku. Sertifikat itu akan diterbitkan kembali oleh Badan ketika masa aktif sertifikat itu habis dan akan diperpanjang kembali. Untuk mensukseskan Undang-undang Jaminan Produk Halal (UU JPH) tersebut, Pemerintah pusat dan daerah wajib mensosialisasikan Undang-Undang JPH ke berbagau pihak, kemudian mendesak pemerintah untuk segera membentuk BPJPH baik pusat maupun daerah.

Makanan bukan hanya sekedar untuk menjaga kesehatan dan mempertahankan hidup, tetapi juga berpengaruh dalam membentuk kepribadian dan karakter seseorang. Artinya makanan sangatlah berpengaruh bagi jasmani maupun rohani orang itu sendiri.

Secara etimologi, kata halalan berarti halhal yang boleh dan dapat dilakukan karena

${ }^{30}$ Muhammad Nadzaratuzzaman Husen, 2008, PanduanUmumSistemJaminan Halal LPPOM MUI, Kata pengantar. bebas atau tidak terikat dengan ketentuanketentuan yang melarangnya. Sedangkan thayyib berarti lezat, naik, sehat dan menentramkan.

Dalam konteks makanan berarti makanan yang tidak kotor dari segi zatnya atau rusak (kadaluwarsa), atau tercampur benda najis dan ada juga yang mengartikan sebagai makanan yang mengundang selera, sehat, proporsional dan aman. Kehalalan makanan atau keharaman makanan produk olahan sangat tergantung dari bahan baku, tambahan, dan atau penolong dan proses produksinya. ${ }^{31}$

Kemajuan teknologi saat ini, menyebabkan sukar membedakan mana yang halal dan mana yang haram. Apalagi jika makanan itu sudah mengalami proses setengah jadi ataupun yang sudah siap. Produk makanan dan kecantikan harus halal karena bukan karena penduduk di Indonesia mayoritas beragama Islam saja. Karena saat ini meski pelaku usaha itu Muslim, tetapi bahan yang dipakai belum tentu halal.

Karena itu Kemenag kota Medan ini hadir untuk melihat dan mengeluarkan sertifikat halal. Pengusaha Muslim harus berkembang dan jangan kalah dengan pengusaha non Muslim dengan mencantumkan label halal makanan. Sudah saat nya kaum Muslim menjadi pengusaha di negeri sendiri bahwa mencari keuntungan dalam berdagang itu harus, tetapi jangan mencari keuntungan dengan menggadaikan keimanan kepada Allah. Jangan hanya dengan menggunakan logo Bismillah dan yang berjualan memakai jilbab sudah dianggap halal padahal ini harus melalui proses sejalan dengan hukum Islam

Dalam perkembangannya, telah diundangkan pada tanggal 3 Mei 2019

${ }^{31}$ Muhammad Yusuf Qardhawi, Halal dan Haram Dalam Islam, PT Binal Imu, Jakarta, 1993, hal. 10 
Media Komunikasi dan Informasi Hukum dan Masyarakat

peraturan pelaksana dari Undang-undang Produk Halal yaitu Peraturan Pemerintah Nomor 31 Tahun 2019 tentang Peraturan Pelaksanaan Undang-Undang Nomor 33 Tahun 2014 tentang Jaminan Produk Halal ("PP 31/2019"). Lebih ditegaskan lagi dalam Pasal 2 ayat (2), ayat (3), dan ayat (4) PP 31/2019 bahwa produk yang berasal dari bahan yang diharamkan dikecualikan dari kewajiban bersertifikat halal dan wajib diberikan keterangan tidak halal serta pelaku usaha wajib mencantumkan keterangan tidak halal pada produk tersebut.

Ketentuan mengenai gambar, tanda, dan/atau tulisan tersebut harus mencakup pelindungan dan hak asasi manusia terhadap kelompok rentan, khususnya penyandang disabilitas, antara lain berupa menjamin pemenuhan hak penyandang disabilitas dalam kemudahan mendapatkan informasi kehalalan produk yang disesuaikan dengan kemampuan penyandang disabilitas yang bersangkutan. Sebagai contoh yaitu tersedianya gambar, tanda, dan/atau tulisan dalam huruf braille bagi penyandang disabilitas yang mengalami masalah dalam penglihatan. Jadi, berdasarkan uraian di atas, jelas bahwa masyarakat seharusnya tidak perlu khawatir karena memang bagi produk yang halal harus ada label halalnya, sedangkan produk yang berasal dari bahan yang diharamkan harus juga mencantumkan keterangan tidak halal.

\section{Penutup}

\section{A. Kesimpulan}

1. Prosedur untuk mendapatkan sertifikasi halal pada restoran hotel yang dikeluarkan oleh ke Kementrian agama (Kemenag), pelaku usaha harus memenuhi persyaratan yang diperiksa oleh BPJPH antara lain data pelaku usaha, nama dan jenis produk usaha, daftar produk dan bahan digunakan, cara atau proses pengolahan produk serta sistim jaminan halal. Setelah memenuhi syarat BPJPH melakukan pemeriksaan dokumen selanjut menetapkan LPH yang telah dipilih oleh pemohon kemudian LPH melakukan Pemeriksaan dan /atau pengujian kehalalan produk langkah berikutnya MUI melalui penetapan kehalalan produk makanan halal melalui sidang fatwa halal. Setelah proses terlaksana melaui tahapan yang ditentukan, maka BPJH menerbitkan sertifikat halal.

2. Urgensinya sertifikat halal pada produk makanan di restoran hotel syariah harus ada dan dilengkapi dengan administrasi dan sarana prasarana sesuai ketentuan sehingga dengan jelas diketahui oleh konsumen, sehingga dapat menciptakan kenyamanan dan keamanan komsumen, terutama kepada komsumen muslim. Untuk memberikan kepastian kehalalan produk makanan bagi umat muslim para produsen yang memproduksi makanan harus mencantumkan tulisan label halal yang dikeluarkan oleh Kemenag bukan lagi dari MUI sehingga pada produk makanan halal dapat membedakan dalam penempatan produk makanan non halal dengan tujuan untuk memberikan kenyamanan terhadap konsumen muslim melalui media tulisan dan sarana tulisan dalam bentuk label yang ditempelkan langsung pada bungkus kemasan makanan yang terbungkus atau ditempel pada tempat tertentu yang tidak mudah hilang, mudah dikenali, mudah dilihat dan mampu meyakinkan bahkan mampu memberikan kepastian kehalalan produk tersebut. 
Media Komunikasi dan Informasi Hukum dan Masyarakat

\section{DAFTAR PUSTAKA}

Ahmadi Miru \& Sutarman Yodo. Hukum Perlindungan Konsumen. Rajawali Pers, Jakarta, 2008

Arnia, Warganegara, E. Identifikasi Kontaminasi Bakteri Coliform Pada Daging Sapi Segar Yang Dijual Di Pasar Sekitar Kota Bandar Lampung. Majority (Medical Journal of Lampung University), 2013.

Arya Wardhana, Wisnu. Dampak Pencemaran Lingkungan. Yogyakarta: Penerbit Andi Yogyakarta., 2004.

Din Syamsuddin, Rabu, 5 Maret 2014, Sertifikasi Halal Negara Non Muslim Lebih Baik, Harian Republika, Jakarta: Republika.

Direktorat Jenderal Bimas Islam dan Penyelenggaraan Haji Departemen Agama, 2003.

H. Roichan Muchlis, "Halal Mendongkrak Ekonomi Bali", Jurnal Halal, No.97 Th. XV Tahun 2012, Jakarta: LPPOM MUI.

KN. Sofyan Hasan, "Cita Hukum (rechtsidee) dan Cita Negara (staatsidee) sebagai Landasan Hukum Indonesia", Jurnal Hukum, Vol. VIII No. 2 Tahun 2010, Palem- bang: Program Pascasarajana Univ. Sriwijaya.

Ma'ruf Amin, "25 Tahun LPPOM MUI, Luncurkan PRO HALAL MUP', Jurnal Halal, No. 106 Tahun 2014, Jakarta : LPPOM MUI.

Ma'ruf Amin, "Fatwa Halal Melindungi Umat dari Ke- rugian yang Lebih Besar", Jurnal Halal, No.103 Th. XVI Tahun 2013, Jakarta: LPPOM MUI.

Ma'ruf Amin, "Mengapa Keharaman Babi Bersifat Mutlak", Jurnal Halal, No.99 Th. XVI Tahun 2013, Jakarta: LPPOM MUI.

Muhammad Yusuf Qardhawi, Halal dan Haram Dalam Islam, PT Binal Imu, Jakarta, 1993.

Paulus J. Rusli, "Nilai Unggul Produk Halal", Jurnal Halal, Nomor 59 Th X, 2005, Jakarta: LPPOM MUI.

Rudolf Stamler dalam Roeslan Saleh, "Pembinaan Cita Hukum dan
Penerapan Asas-asas Hukum Nasional', Ma- jalah Hukum Nasional, No. 1 tahun 1995, Jakarta.

Sabiq, Sayyid, Fikih Sunah, Bandung : PT Alma'arrif 1997.

Sandiago Uno, "Agar UKM Semakin Berdaya Saing Ting- gi" Jurnal Halal, No. 91 Th. XIV Tahun 2011, Jakarta: LPPOM MUI.

Sjarif Hasan, "Pemerintah Dorong Sertifikasi Halal UKM', Jurnal Halal, No.91 Th. XIV Tahun 2011, Jakarta: LPPOM MUI.

Syaikh Al-Fauzan,Al-Ath'imah wa Ahkamis Shoyd wadz Dzaba'ih, Maktabah AlMa'arif Ar-Riyadh, 1988.

Syarief, R. dan S. Santausa. Teknologi Pengemasan Pangan. Laboratorium Rekayasa Proses Pangan, PAU Pangan dan Gizi, IPB. 2010.

Wati Rahmi Ria dan Muhammad Zulfikar, IImu Hukum Islam, Gunung Pesagi, Bandar Lampung, 2015. 